\title{
Biomass Reducing Potential and Prospective Fungicide Control of a New Leaf Blight of Miscanthus $\times$ giganteus Caused by Leptosphaerulina chartarum
}

\author{
Monday O. Ahonsi - Keith A. Ames • Michael E. Gray • \\ Carl A. Bradley
}

Published online: 11 January 2013

(C) The Author(s) 2013. This article is published with open access at Springerlink.com

\begin{abstract}
During a multistate survey (2009) of diseases of perennial grasses under consideration as biofuel feedstocks, a new leaf blight of Miscanthus $\times$ giganteus caused by Leptosphaerulina chartarum was observed on $100 \%$ of the plants evaluated in research plots near Lexington, Kentucky. A greenhouse study was conducted to evaluate the effect of L. chartarum on M. $\times$ giganteus biomass and to identify effective foliar fungicides against the disease. Eleven broad-spectrum fungicides were tested with rates typically used in agronomic crops. Fungicides tested included active ingredients from five different chemical groups, demethylation inhibitors (prothioconazole, tebuconazole, cyproconazole, propiconazole, tetraconazole, flutriafol, and metconazole), quinone outside inhibitors (pyraclostrobin), succinate dehydrogenase inhibitors (boscalid), methyl benzimidazole carbamates (thiophanate-methyl), and chloronitriles (chlorothalonil). Infection by L. chartarum significantly lowered aboveground biomass by an average of $33 \%$. Application of cyproconazole, flutriafol, tebuconazole, or prothioconazole significantly reduced disease severity, with cyproconazole and flutriafol ranking best at an average of $29 \%$ disease control. However, no fungicide treatment resulted in biomass loss abatement. Greater rates or a combination of fungicides might be needed to achieve adequate control.
\end{abstract}

\footnotetext{
M. O. Ahonsi $(\bowtie) \cdot$ M. E. Gray • C. A. Bradley

Energy Biosciences Institute, University of Illinois,

1206 W. Gregory Dr,

61801 Urbana, IL, USA

e-mail: mahonsi@igb.illinois.edu

K. A. Ames $\cdot$ M. E. Gray $\cdot$ C. A. Bradley

Department of Crop Sciences, 1102 S. Goodwin,

61801 Urbana, IL, USA
}

Keywords Bioenergy · Disease $\cdot$ Feedstock · Fungicide · Pithomyces chartarum $\cdot$ Miscanthus

\section{Introduction}

Miscanthus $\times$ giganteus is a high-yielding, rhizomatous C4perennial grass considered to be a highly promising biomass feedstock for renewable biofuel production [4, 17]. At differing times, M.× giganteus has been called Miscanthus sinensis 'Giganteus', Miscanthus giganteus, Miscanthus ogiformis Honda, Miscanthus sacchariflorus var brevibarbis (Honda) Adati, and M.×giganteus (Greef \& Deuter ex Hodkinson \& Renvoize) [4, 18]. M.× giganteus is a sterile triploid interspecific natural hybrid of $M$. sinensis Anderss and M. sacchariflorus (Maxim.) Hack and is native to tropical and subtropical regions of Africa and southern Asia and temperate Eastern Asia [18]. Its high biomass accumulation potential is due to its $\mathrm{C} 4$ photosynthesis (which means greater rates of carbon fixation) and greater water and nutrient-use efficiency as is typical of C4- grasses $[4,16,17]$. Naturally established hybrid vigor in $M$.× giganteus also could be an important factor that set it apart from many other similar grass species (even its natural parents, M. sinensis and M. sacchariflorus) in its ability to withstand stress, adapt to a wide range of environments, and more efficiently convert solar energy into biomass energy, therefore providing a high biomass/input ratio per cultivated land area [4, 16, 17]. M.× giganteus has been thought to be mostly free of damage from diseases and pests, an important trait that probably contributes to its high biomass yields even under a system using fewer inputs. Pest resistance and a perennial habit are two traits that would contribute to an ideal biofuel feedstock candidate $[4,17]$. 
The limited number of reported pest infestations and diseases in $M$. $\times$ giganteus may partially be due to the limited scope of research conducted in this area, as well as the relatively small portion of agricultural land worldwide devoted to M. $\times$ giganteus production. As more and more plots of M. $\times$ giganteus and other Miscanthus spp are established for research in different agroecological zones of the world due to the escalating interests in second-generation biofuels, diseases of Miscanthus spp (including M. $\times$ giganteus) are beginning to emerge $[2,3,5,6,14,23,24]$. As this new crop goes into more intensive monoculture systems, it will begin to succumb to the pressure of pathogens that also are continually evolving to find new hosts. The risk of development of disease epidemics that could severely limit biomass production is particularly high for the M.× giganteus clone which is propagated from rhizome cuttings, and lacks genetic diversity. During our multistate survey (2009) of diseases in perennial grasses of potential use as feedstocks for biofuels, a severe occurrence of a new leaf blight of M.× giganteus (Fig. 1) was found in research plots near Lexington, Kentucky. The disease was determined to be caused by the fungus, Leptosphaerulina chartarum (anamorph: Pithomyces chartarum) [2]. Incidence of the disease was $100 \%$ in both 2-year-old and first-year M.× giganteus plots. Damage was particularly severe on the first-year crop, where some tillers were killed [2].

L. chartarum has been known to be an important ascomycetous fungus, not because it causes plant diseases, but because of the worldwide mycotoxicosis of ruminant animals from its potent toxic metabolite sporidesmin produced in its spores and ingested through grazing on infected pastures $[1,8,12,15,19,21,29,33]$. Sporidesmin, a hepatotoxin produced by the fungus is associated with 'pithomycotoxicosis' (or pithomyces poison-induced liver damage), a potentially fatal photosensitization disease of sheep and other grazing ruminants, commonly referred to as 'facial eczema' because of its post-liver-damage symptoms [8,9]. In addition to a recent report of the Pithomyces blight of M. $\times$ giganteus [2], there have been sporadic reports of diseases that $L$. chartarum causes on plants $[10,32,34]$. Wilkinson [36] found masses of dark spores in July and August during 1985 and 1986 as bluegrass sod (Poa pratensis L.) was being mowed at several farms in Illinois, Indiana, and Wisconsin. The fungus was isolated and identified as L. chartarum. It was the first report of the fungus in the north central USA and the first report of the fungus in bluegrass sod where it appeared to be saprophytic [36].

Pithomyces blight in M. $\times$ giganteus plots (Kentucky, 2009) [2] severely affected growth and plant establishment. However, the loss could not be estimated because the disease incidence was $100 \%$. The need for an effective control of $L$. chartarum has long been recognized, particularly in grass pastures due to its economic importance as a mycotoxigenic fungus. Some efforts directed at biological control using non-toxigenic Leptosphaerulina strains based on the competitive exclusion principle $[7,11]$ and use of chemical fungicides $[25,26,28,30,37]$ have been made in the past but without any significant success. The objectives of our current study were to: (1) evaluate the potential effect of Pithomyces blight on M. $\times$ giganteus biomass and (2) determine the efficacy of selected fungicides for control of Pithomyces blight on M. $\times$ giganteus.
Fig. 1 Pithomyces blight on a first-year crop of $M . \times$ giganteus and $\mathbf{b}$ second-year crop of $M . \times$ giganteus in research plots new Lexington, Kentucky, in 2009

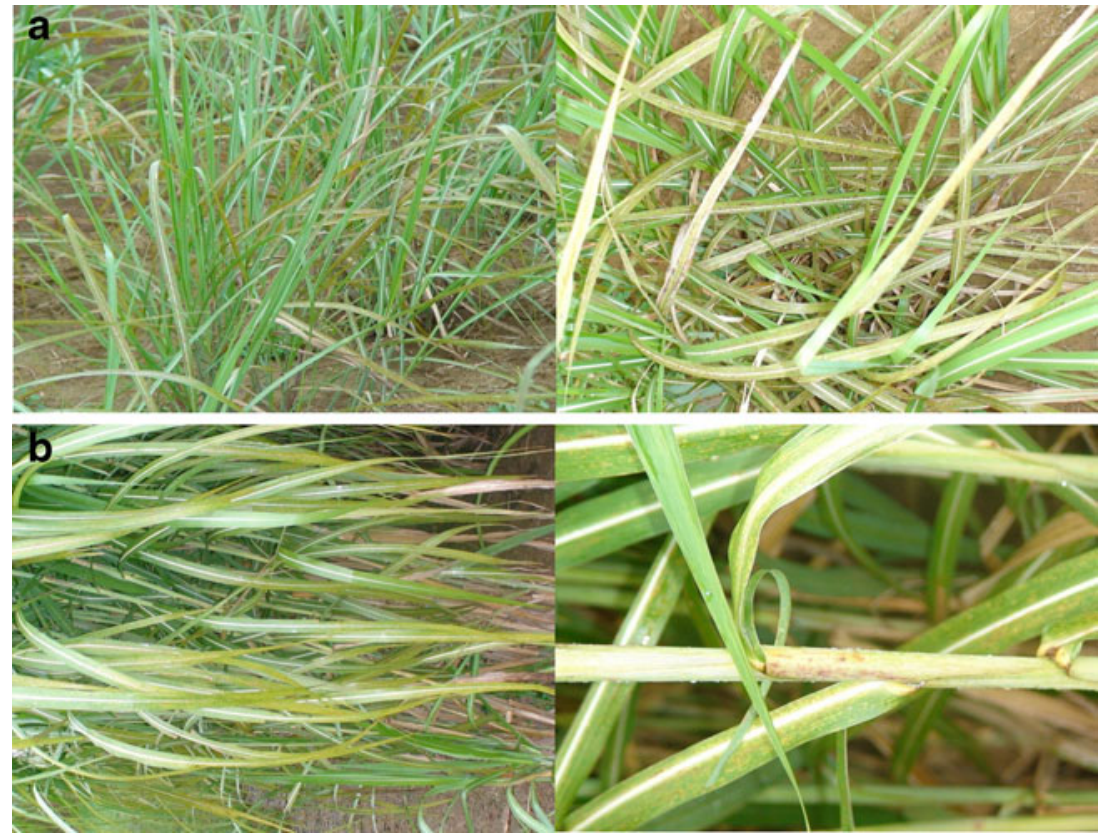




\section{Materials and Methods}

Three experiments ("1", "2a," and " $2 \mathrm{~b}$ ") were conducted to determine the effect of Pithomyces blight on M. $\times$ giganteus biomass and screen fungicides for their efficacies to control the disease.

\section{Fungicides Tested}

In experiment 1 , five broad-spectrum fungicide active ingredients (chlorothalonil, boscalid, pyracclostrobin, proclostrobin, prothioconazole, and thiophanate-methyl) from five different chemical groups (Table 1) were evaluated. In experiments $2 \mathrm{a}$ and $2 \mathrm{~b}$, six additional fungicide active ingredients from the demethylation inhibitor (DMI) fungicide group were added to the screening experiment (Table 2). Thus, 11 broad-spectrum fungicide active ingredients from five different fungicide groups (Table 1) were tested in experiments $2 \mathrm{a}$ and $2 \mathrm{~b}$. They included seven fungicides in the DMI group (prothioconazole, tebuconazole, cyproconazole, propiconazole, tetraconazole, flutriafol, and metconazole) and one fungicide within each of the other four fungicide groups: thiophanate-methyl (methyl benzimidazole carbamate group (MBC)), boscalid (succinate dehydrogenase inhibitor group (SDHI)), pyraclostrobin (quinone outside inhibitor group (QoI)), and chlorothalonil (chloronitrile group).

\section{The Test Plant $M . \times$ giganteus}

M. × giganteus 'Illinois' plants used for this study were established from 'plugs' (live plants generated in the greenhouse) supplied by Speedling, Inc. (Speedling Inc. Sun City, FL, USA). M. $\times$ giganteus plugs received from Speedling, Inc., were immediately removed from the shipment boxes and planted in $12 \times 4$ channel plastic inserts placed in plastic flats to re-establish growth in the greenhouse with a 15-h photoperiod, day temperature of $24-27^{\circ} \mathrm{C}$, and night temperature of $21-24{ }^{\circ} \mathrm{C}$. MetroMix 510 growing mix (Sungro Horticulture Canada LTD., Bellevue, WA) (35-45 \% Canadian Sphagnum peat moss horticulture grade vermiculite, composted pine bark, bark ash, and dolomitic limestone) was used as the growing medium.

Approximately 2 weeks later, after new leaves developed and the plants were established, plants were transplanted from the inserts into individual $12.7-\mathrm{cm}$ plastic pots $(0.6 \mathrm{~L})$ containing Metro-Mix 510 growing mix. The potted plants were grown in the greenhouse under the same conditions previously described for an additional 2 to 3 weeks. Then, uniformly sized plants ( $4-5$ weeks old, five to six leaves, and average height of $25 \mathrm{~cm}$ ) were arbitrarily selected for the fungicide evaluation experiment. The growing mix within each pot was surface-dressed with slow release fertilizer, osmocote 15:9:12 (The Scotts Company LLC, Marysville, $\mathrm{OH}$ ), at the time of transplanting at the rate of $2 \mathrm{~g}$ fertilizer per pot.

Production of $L$. chartarum Inoculum

Single-spore L. chartarum isolate Mxg-KY09-s4 (GU195649.1), isolated from symptomatic M.×giganteus plants near Lexington, Kentucky, USA, in 2009 [2], was used in this study. The fungal isolate was grown on halfstrength potato dextrose agar (Oxoid Ltd, Basingstoke, Hampshire, England) amended with $25 \mathrm{mg} / 1$ of rifamycin sulfate. The $100 \times 15 \mathrm{~mm}$ agar plates were initially incubated at $22{ }^{\circ} \mathrm{C}$ for 3 days in the dark, then under continuous white light for 2 weeks.

To prepare spore inoculum, Petri dish agar cultures were flooded with $20 \mathrm{ml} /$ plate of sterilized water containing $0.05 \%(v / v)$ Tween-20 as a wetting agent, and then cultures were scraped with microscope glass slides to loosen the mycelia and release conidia into the water. A collection of the conidia and mycelia suspension from all the culture plates was blended using a hand blender (Cuisinart Smart Stick Hand Blender Model CSB-76, Cuisinart, East Windsor, NJ). The blended spore suspension was then filtered through double layers of cheese cloth. The inoculum was adjusted to an approximate concentration of $2 \times 10^{6}$ conidia/ml.

Fungicide Application

A single dose of fungicide was applied to the $M$. $\times$ giganteus plants $24 \mathrm{~h}$ prior to plant inoculation with pathogen inoculum at rates (Table 1) typically used in agronomic crops. In preparation to spray the plants, each of the 11 fungicides was diluted to final application concentration (Table 1) with sterile water. The designated fungicide was applied as uniform fine sprays onto the M.× giganteus leaves using an automated pesticide spray containment chamber with a 80015EVS spray nozzle (Spraying Systems Co., Wheaton, IL) calibrated to deliver $187 \mathrm{~L} /$ ha. M.× giganteus plants designated as no fungicide (control) were sprayed with sterile water. The plants were allowed to air-dry outside the spray chamber for 1 to $2 \mathrm{~h}$ and then moved to the growth chamber room where they would be inoculated and incubated.

Plant Inoculation and Incubation for Infection

M. $\times$ giganteus plants were hand-spray-inoculated with an aqueous conidial suspension (approx. $2 \times 10^{6}$ conidia/ml) using a Preval spray gun (Preval, 1300 E North Street Coal City, IL) $24 \mathrm{~h}$ after fungicide application. They were 


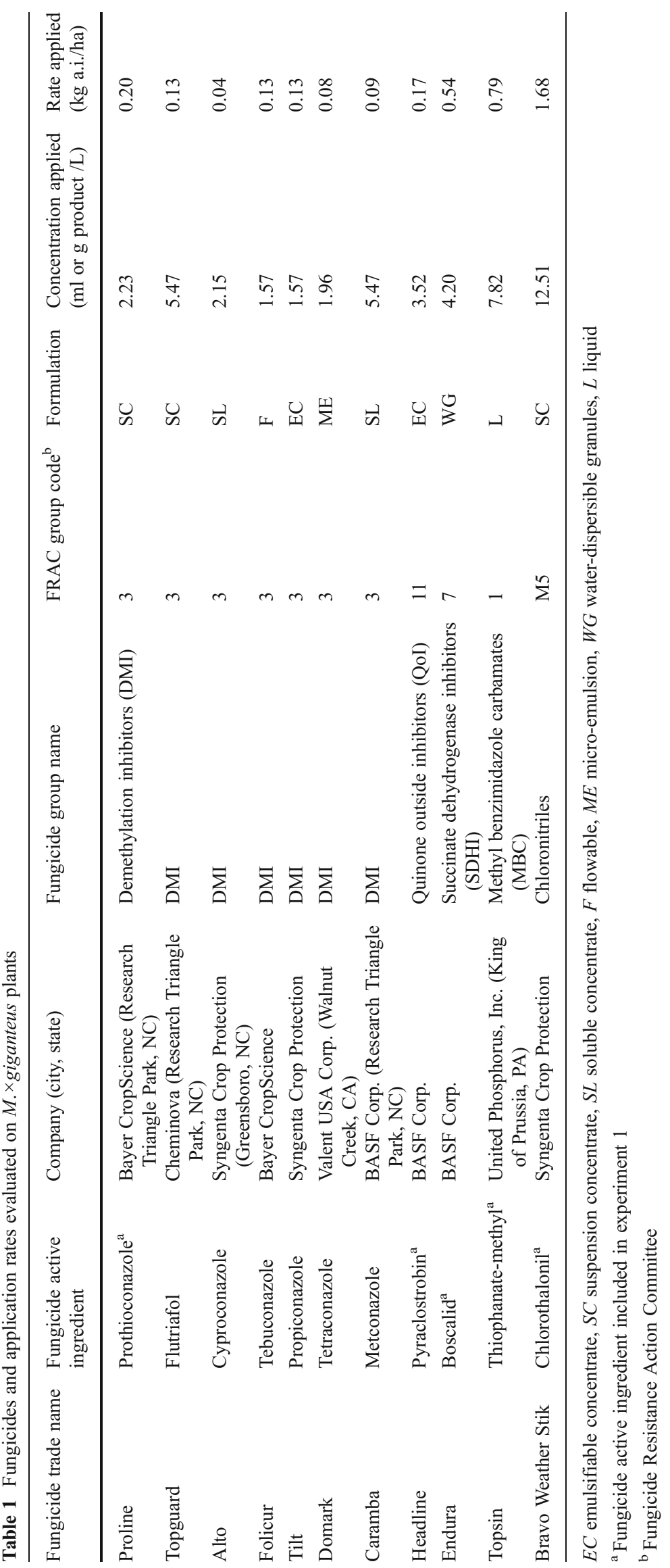


Table 2 Effect of fungicide spray on the severity of Pithomyces blight on $M$. $\times$ giganteus under greenhouse conditions in experiment 1
$N S$ not significant (at $P \leq 0.05$ )

${ }^{\mathrm{a}}$ Compared with no-fungicide-inoculated

$* P \leq 0.05, * * P \leq 0.01$ levels of significance

\begin{tabular}{|c|c|c|c|c|}
\hline \multirow{3}{*}{$\begin{array}{l}\text { Fungicide treatment } \\
\text { (fungicide active ingredient) }\end{array}$} & \multicolumn{4}{|c|}{ Percent disease severity } \\
\hline & \multicolumn{2}{|c|}{15 days after inoculation } & \multicolumn{2}{|c|}{23 days after inoculation } \\
\hline & Mean & $\begin{array}{l}\text { Disease reduction by } \\
\text { fungicide }(\%)^{\mathrm{a}}\end{array}$ & Mean & $\begin{array}{l}\text { Disease reduction by } \\
\text { fungicide }(\%)^{\mathrm{a}}\end{array}$ \\
\hline No fungicide & 47.1 & & 49.5 & \\
\hline Chlorothalonil & 30.9 & $34.3 \mathrm{NS}$ & 39.7 & $19.7 \mathrm{NS}$ \\
\hline Boscalid & 40.6 & $13.8 \mathrm{NS}$ & 45.7 & $7.6 \mathrm{NS}$ \\
\hline Pyraclostrobin & 37.0 & $21.4 \mathrm{NS}$ & 47.1 & $4.8 \mathrm{NS}$ \\
\hline Prothioconazole & 18.4 & $61.0 * *$ & 25.2 & $49.0 *$ \\
\hline Thiophanate-methyl & 32.8 & $30.3 \mathrm{NS}$ & 42.9 & $13.3 \mathrm{NS}$ \\
\hline $\mathrm{SE}( \pm)$ & 4.94 & & 5.73 & \\
\hline$P>F$ & 0.0097 & & 0.0734 & \\
\hline
\end{tabular}

then incubated in growth chambers (Conviron CMP6050 model \# MTR26, Controlled Environment Limited). The plants were maintained in the dark at relative humidity of $>85 \%$, and at $26{ }^{\circ} \mathrm{C}$ for $48 \mathrm{~h}$ initially following inoculation, and thereafter at alternating $15 \mathrm{~h}$ of $280 \mu \mathrm{mol}$ light at $25{ }^{\circ} \mathrm{C}$ and $9 \mathrm{~h}$ of darkness at $23{ }^{\circ} \mathrm{C}$ until 2 week after inoculation. Thereafter, the plants were moved back to the greenhouse.

Disease Development in the Greenhouse and Data Collection

Following initial 1 week incubation in growth chamber, plants in all three experiments were maintained in the greenhouse with a 15 -h photoperiod and day and night temperatures of $24-27{ }^{\circ} \mathrm{C}$ and $21-24{ }^{\circ} \mathrm{C}$. In experiment 1 , the plants were left in the greenhouse only until the last disease assessment (at day 23 after inoculation). In experiment $2 \mathrm{a}$ and $2 \mathrm{~b}$, the plants were maintained for 15 and 11 additional weeks in the greenhouse, respectively. During this period, the plants were lightly watered twice a day to meet the water need of the plants and to maintain adequate relative humidity for infection and disease development. To limit assessment to only the treated tillers, new and emerging tillers were removed regularly.

Disease severity was assessed as 'percent disease severity' per plant at 15 and 23 days after inoculation in experiment 1 and at 4 weeks after inoculation in experiment $2 \mathrm{a}$ and $2 \mathrm{~b}$. The percentage of leaf surface area covered by disease symptoms (compared with green tissues) on each of the three most infected leaves on a plant was estimated visually. Then, these estimates were averaged to get the percent disease severity per plant. Plant biomass accumulation was measured at 16 (for experiment 2a) or 12 weeks (for experiment 2b) after inoculation as 'aboveground dry-weight.' The aboveground part (shoot and leaves) of each plant was harvested, air-dried for 2 weeks in labeled brown bags on a greenhouse bench at $27{ }^{\circ} \mathrm{C}$ $30{ }^{\circ} \mathrm{C}$, and then weighed to obtain the aboveground dry-weight per plant.

\section{Experimental Design and Statistical Analysis}

In the preliminary experiment (experiment 1 ), there were six fungicide treatments which included five 'fungicide-inoculated' treatments and one control which was 'no fungicide (sterile water applied)-inoculated.' In experiment $2 \mathrm{a}$ or $2 \mathrm{~b}$ (experiment $2 \mathrm{~b}$ is a repeat of $2 \mathrm{a}$ ), there were 13 treatments, including 11 'fungicide-inoculated' treatments and two controls which were 'no fungicide-inoculated' and 'no fungicide-non-inoculated.'

Each experiment was designed as a randomized complete block design with eight blocks. Each potted plant (0.6-L pot) served as both an experimental and observational unit. For experiments $2 \mathrm{a}$ and $2 \mathrm{~b}$, with 13 treatments, each block was contained within a space of $0.55 \times 0.55 \mathrm{~m}$, with the eight blocks allocated to three greenhouse benches.

To provide a better understanding of the treatment responses in the repeated experiments, the percent disease severity or the aboveground $M . \times$ giganteus dry-weight per pot data were analyzed by experiment and as a pooled dataset. Data were subjected to analysis of variance (ANOVA) in SAS (SAS version 9.3, SAS Institute Inc., Cary, NC, USA) using the MIXED procedure [22]. Replication and experiment (for pooled data) were treated as random effects and treatment as a fixed effect in the model statement. To normalize percent disease severity data, they were arcsine-transformed. Also, since no disease was observed in the 'No inoculation' control, it was expunged from the ANOVA of the percent disease severity. Singledegree-of-freedom contrasts were made to test differences between specific treatment means with the mean of a control. 


\section{Results}

Disease Severity and the Effect of Fungicide Application

Pithomyces blight of Miscanthus was observed in all inoculated M.× giganteus plants in all three experiments, but the average percent disease severity per plant varied according to fungicide treatment. In experiment 1, percent disease severity on $M . \times$ giganteus plants to which the DMI prothioconazole had been applied was significantly lower by $61 \%$ $(P \leq 0.01)$ and $49 \%(P \leq 0.05)$ at 15 and 23 days after inoculation, respectively, compared with plants to which no fungicide was applied (Table 2).

There was reduced disease severity with each of the 11 fungicide treatments tested in experiment $2 \mathrm{a}$ and $2 \mathrm{~b}$ compared with the no fungicide control, but only in a few fungicide treatments were reductions significant at the $5 \%$ probability level (Table 3). Only applications of cyproconazole, flutriafol, prothioconazole, or tebuconazole, all of which belong to the DMI fungicide group, significantly $(P \leq 0.05)$ reduced disease severity compared with the control (Table 3). Cyproconazole and flutriafol were the most effective across trials, with an average disease reduction of $29 \%$ (Table 3 ). These were followed by tebuconazole (27\% disease reduction) and prothioconazole (25\% disease control) (Table 3).

Another DMI fungicide, tetraconazole, significantly lowered disease levels in experiment $2 b$ but not in experiment 2a. Similarly, inconsistent results were obtained for pyraclostrobin (quinone outside inhibitor) and boscalid (succinate dehydrogenase inhibitor) applications in the three experiments (Tables 2 and 3).

Biomass Reduction Potentials of Pithomyces Blight of Miscanthus and the Effect of Fungicide Application

M.× giganteus plants infected with Pithomyces blight following inoculation with $L$. chartarum consistently resulted in significantly $(P \leq 0.05)$ lower harvestable above-ground plant biomass compared with non-inoculated plants (Table 4). There was an average biomass reduction of $33 \%(P \leq 0.01)$ when plants were inoculated with $L$. chartarum and not treated with a fungicide compared with disease-free plants that also were not treated with a fungicide (Table 4). None of the tested fungicide active ingredients (including the four DMI fungicides that significantly reduced disease severity (Table 3 )) resulted in biomass loss abatement at the application rate used (Table 4). M.× giganteus plants that were sprayed with fungicides and inoculated with L. chartarum had lower above-ground biomass compared with the non-inoculated plants $(P>0.05)$ (Table 4$)$.

\section{Discussion}

Results of our experiments (Tables 3 and 4) have demonstrated that infection of $M . \times$ giganteus plants by the pathogen $L$. chartarum could result in biomass loss of $M \times$ giganteus. The effect of the severe incidence of Pithomyces blight of $M . \times$ giganteus in research plots near
Table 3 Effects of fungicide spray on the severity of Pithomyces blight of Miscanthus on $M . \times$ giganteus under greenhouse conditions 4 weeks after inoculation
$N S$ not significant (at $P \leq 0.05$ )

${ }^{\mathrm{a} C}$ Compared with no-fungicide-inoculated ${ }^{*} P \leq 0.05,{ }^{* *} P \leq 0.01$, $* * * P \leq 0.001$ levels of significance

\begin{tabular}{|c|c|c|c|c|c|c|}
\hline \multirow{3}{*}{$\begin{array}{l}\text { Fungicide treatment } \\
\text { (fungicide active ingredient) }\end{array}$} & \multicolumn{6}{|c|}{ Percent disease severity } \\
\hline & \multicolumn{2}{|c|}{ Experiment $2 \mathrm{a}$} & \multicolumn{2}{|c|}{ Experiment $2 \mathrm{~b}$} & \multicolumn{2}{|c|}{$\begin{array}{l}\text { Experiment } 2 \mathrm{a} \text { and } 2 \mathrm{~b} \\
\text { combined }\end{array}$} \\
\hline & Mean & $\begin{array}{l}\text { Disease } \\
\text { reduction }(\%)^{\mathrm{a}}\end{array}$ & Mean & $\begin{array}{l}\text { Disease } \\
\text { reduction }(\%)^{\mathrm{a}}\end{array}$ & Mean & $\begin{array}{l}\text { Disease } \\
\text { reduction }(\%)^{a}\end{array}$ \\
\hline No fungicide & 40.2 & & 61.8 & & 51.0 & \\
\hline Cyproconazole & 27.9 & $30.8 *$ & 44.2 & $28.4 * * *$ & 36.1 & $29.3 * *$ \\
\hline Chlorothalonil & 32.9 & $18.3 \mathrm{NS}$ & 56.8 & $8.1 \mathrm{NS}$ & 44.8 & $12.1 \mathrm{NS}$ \\
\hline Metconazole & 34.7 & $13.8 \mathrm{NS}$ & 53.8 & $12.9 \mathrm{NS}$ & 44.3 & $13.2 \mathrm{NS}$ \\
\hline Tetraconazole & 32.6 & $19.0 \mathrm{NS}$ & 49.4 & $20.0 *$ & 40.1 & 19.6 NS \\
\hline Boscalid & 32.5 & $19.3 \mathrm{NS}$ & 49.4 & $20.0^{*}$ & 41.0 & $19.7 \mathrm{NS}$ \\
\hline Tebuconazole & 30.1 & $25.2 \mathrm{NS}$ & 44.6 & $27.7 * * *$ & 37.4 & $26.7^{*}$ \\
\hline Pyraclostrobin & 26.5 & $34.1 * *$ & 52.0 & 15.9 NS & 39.3 & $23.1 \mathrm{NS}$ \\
\hline Prothioconazole & 27.9 & $30.7^{*}$ & 48.6 & $21.3 * *$ & 38.5 & $24.6^{*}$ \\
\hline Propiconazole & 32.0 & $20.5 \mathrm{NS}$ & 53.5 & $13.4 \mathrm{NS}$ & 42.7 & $16.2 \mathrm{NS}$ \\
\hline Flutriafol & 28.0 & $30.4 *$ & 44.2 & $28.4 * * *$ & 36.1 & $29.2 * *$ \\
\hline Thiophanate-methyl & 29.4 & $26.9 \mathrm{NS}$ & 50.2 & $18.8 \mathrm{NS}$ & 39.8 & $22.0 \mathrm{NS}$ \\
\hline $\mathrm{SE}( \pm)$ & 2.93 & & 2.95 & & 3.25 & \\
\hline$P>F$ & 0.0905 & & 0.0011 & & 0.0674 & \\
\hline
\end{tabular}


Table 4 Effects of Pithomyces blight of Miscanthus on M. $\times$ giganteus biomass and the ability of fungicide spray to mitigate biomass loss

\begin{tabular}{|c|c|c|c|c|c|c|}
\hline \multirow{3}{*}{$\begin{array}{l}\text { Fungicide treatment } \\
\text { (fungicide active ingredient) }\end{array}$} & \multicolumn{6}{|c|}{ Aboveground $M . \times$ giganteus biomass ( $\mathrm{g}$ dry-weight per pot) } \\
\hline & \multicolumn{2}{|c|}{ Experiment $2 \mathrm{a}$} & \multicolumn{2}{|c|}{ Experiment $2 b$} & \multicolumn{2}{|c|}{$\begin{array}{l}\text { Experiment } 2 \mathrm{a} \text { and } 2 \mathrm{~b} \\
\text { combined }\end{array}$} \\
\hline & Mean & $\begin{array}{l}\text { Biomass } \\
\text { reduction }(\%)^{\mathrm{a}}\end{array}$ & Mean & $\begin{array}{l}\text { Biomass } \\
\text { reduction }(\%)^{\mathrm{a}}\end{array}$ & Mean & $\begin{array}{l}\text { Biomass } \\
\text { reduction }(\%)^{\mathrm{a}}\end{array}$ \\
\hline No fungicide-non-inoculated & 37.9 & & 17.5 & & 27.7 & \\
\hline No fungicide-inoculated & 24.3 & $34.9 * * *$ & 12.6 & $28.1 *$ & 18.6 & $32.8 * *$ \\
\hline Cyproconazole & 16.6 & $56.3^{* * *}$ & 14.4 & $17.5 \mathrm{NS}$ & 15.5 & $44.1 * * *$ \\
\hline Chlorothalonil & 24.5 & $35.2 * * *$ & 12.3 & $29.6^{*}$ & 18.4 & $33.5^{* *}$ \\
\hline Metconazole & 24.3 & $36.0 * * *$ & 14.9 & $14.8 \mathrm{NS}$ & 19.6 & $29.3^{*}$ \\
\hline Tetraconazole & 18.8 & $50.3^{* * *}$ & 12.1 & $30.5^{*}$ & 15.5 & $44.1 * * *$ \\
\hline Boscalid & 19.6 & $48.3^{* * *}$ & 12.2 & $30.1^{*}$ & 15.9 & $42.6^{* * *}$ \\
\hline Tebuconazole & 25.0 & $34.0 * * *$ & 09.2 & $47.2 * * *$ & 17.1 & $38.2 * * *$ \\
\hline Pyraclostrobin & 21.2 & $42.7 * * *$ & 10.8 & $38.2 * *$ & 16.2 & $41.3 * * *$ \\
\hline Prothioconazole & 21.6 & $43.0 * * *$ & 12.2 & $30.1 *$ & 16.9 & $38.9 * * *$ \\
\hline Propiconazole & 20.5 & $46.0 * * *$ & 14.1 & $19.5 \mathrm{NS}$ & 17.3 & $37.6 * * *$ \\
\hline Flutriafol & 24.3 & $36.0 * * *$ & 12.2 & $30.4^{*}$ & 18.2 & $34.2 * *$ \\
\hline Thiophanate-methyl & 20.6 & $45.7 * * *$ & 12.1 & $30.9 *$ & 16.3 & $41.0 * * *$ \\
\hline $\operatorname{SE}( \pm)$ & 2.05 & & 1.23 & & 1.84 & \\
\hline$P>F$ & $<0.0001$ & & 0.0032 & & 0.0007 & \\
\hline
\end{tabular}

$N S$ not significant (at $P \leq 0.05$

${ }^{\mathrm{a}}$ Compared with no

fungicide-non-inoculated

$* P \leq 0.05, * * P \leq 0.01$,

$* * * P \leq 0.001$ levels of

significance
Lexington, Kentucky, in 2009 [2] could not be estimated empirically in the field, because of the $100 \%$ incidence. Notwithstanding, severe damage was obvious particularly on the first-year crop, where some tillers were killed. In addition, it was apparent that the leaf blades and sheaths that were covered with the brown, mosaic-like, coalesced necrotic lesions [2] could have had reduced chlorophyll-rich surface area and therefore a significant reduction in the overall photosynthetic efficiency [20], potentially culminating in a reduction in biomass accumulation.

To our knowledge, this is the first study that deliberately estimates the effects of a foliar disease on biomass yield of M. $\times$ giganteus. Prior investigations of the pathogenicity of soil-borne fungi, particularly Fusarium species, on M.× giganteus establishment have been reported in Europe [5, 13]. In 2010, Fusarium avenacerum was implicated as the major (65\%) soil-borne fungus responsible for rhizome rot of Miscanthus that led to an establishment failure of an estimated $90 \%$ of transplanted M.×giganteus rhizomes [5]. About a decade earlier, a study on the role that Fusarium spp. play in field establishment challenges of Miscanthus in Europe (particularly with field establishment of in vitro propagated miscanthus plants) was published by Thinggaard [31]. Of the three Fusarium spp.: Fusarium culmorum, Fusarium avenaceum, and Fusarium moniliforme (tested isolates of which all were previously isolated from Miscanthus roots, rhizomes, and stems in the field), only $F$. culmorum isolates caused severe root rot and reduced root density of $M$. sinensis 'Goliath' and $M$. sinensis
'Giganteus' (M.×giganteus). None of the tested Fusarium isolates significantly reduced the height or dry weight of the two Miscanthus varieties 10 weeks after inoculation under greenhouse conditions [31].

In our study, a direct comparison of inoculated and noninoculated $M . \times$ giganteus plants (Table 4$)$ indicated that a severe infection by $L$. chartarum (Table 3$)$ reduced $(P \leq$ 0.05 ) biomass yield by $35 \%$ and $28 \%$ in two separate experiments under greenhouse conditions. The disease severity and impact on $M . \times$ giganteus growth and biomass accumulation in the greenhouse inoculation experiments may be comparable to the severe incidence observed on first year M.×giganteus research plots near Lexington, Kentucky, in 2009 and the observed, but not measured effect on the establishment of M.× giganteus [2]. The uniform (100\% incidence) infection of $M . \times$ giganteus in the field [2] and in the greenhouse study underscores the potential challenge of using a Miscanthus clone with no genetic variability as a biomass monocrop. The susceptibility of a M. $\times$ giganteus monocrop (particularly a first-year crop) to an aggressive pathogen strain under favorable environmental conditions could mean significant reduced growth, field establishment problems, and loss of biomass harvest and income to a farmer.

This study also represents the first time any management tactics have been attempted for a fungal pathogen of $M . \times$ giganteus. However, investigations conducted to identify effective chemical fungicide treatments for the control of L. chartarum on pasture grasses have been performed 
$[25,26,28,30,37]$ due to the veterinary importance of this fungus $[1,8,12,15,19,21,29,33]$. In our experiments, cyproconazole, flutriafol, prothioconazole, and tebuconazole treatments resulted in consistent and significantly lower disease severity and belonged to the DMI group (Table 3). Early research on the chemical control of the fungus $L$. chartarum, the causative agent of facial eczema, determined that a number of compounds in the $\mathrm{MBC}$ group, which includes thiabendazole, benomyl, carbendazim, and thiophanate-methyl, reduced spore production in pastures [26-28, 30, 35]. Thiabendazole and benomyl reduced spore numbers during periods of accelerated production by $40 \%$ to $90 \%$ for 6 weeks [26]. Wallace [35] evaluated the effectiveness of three fungicides carbendazim, benomyl, and thiophanate methyl in the field and found that a carbendazim pre-danger spore level application (at $0.15 \mathrm{~kg}$ a.i./ha) was effective in significantly reducing $L$. chartarum spore counts in pasture to a below danger level on treated pasture $\left(700 \times 10^{3}\right.$ spores per $\mathrm{m}^{3}$ air). Benomyl and thiophanate methyl also were effective at $0.3 \mathrm{kga}$.i./ha. Only carbendazim at a rate of $0.15 \mathrm{kga}$.i./ha kept the spore count at or below $700 \times 10^{3}$ spores per $\mathrm{m}^{3}$ air [35]. Although spore count reduction cannot be directly translated to plant disease reduction, results from our testing of thiophanate-methyl indicated a consistent but non-significant reduction in Pithomyces blight of M.× giganteus (Tables 2 and 3). Although there was a statistically significant reduction in disease severity when cyproconazole, flutriafol, tebuconazole, or prothioconazole were applied (Table 3), the reduction was not sufficient to mitigate $M . \times$ giganteus biomass loss resulting from the infection by L. chartarum (Table 4).

It is reasonable to expect that more than one application or a higher application dosage of these fungicides, particularly cyproconazole, flutriafol, tebuconazole, and prothioconazole, may be needed to achieve adequate disease control that could result in biomass loss abatement. However, more challenges are expected under field conditions due to rain and other environmental factors that can render the fungicides less effective than under more controlled conditions in growth chambers and the greenhouse. Since the rates typically used for other diseases of agronomic crops in the field were tested in this study, it was expected that any fungicide that can be profitably and sustainably (in environmental sense) used in the field should give a near-complete control under controlled conditions of growth chambers and the greenhouse. The average percent disease severity on $M$. $\times$ giganteus treated with fungicide ranged from $36 \%$ to $39 \%$ for the four best fungicides compared with $51 \%$ for the no fungicide-inoculated control (Table 3). This level of control achieved under greenhouse conditions, though statistically significant, does not seem to be practically promising under field conditions. An alternative approach to using unacceptably high application rates might be to test a combination of different chemical fungicides with different modes of action. For field setting, multiple applications of the fungicides may be necessary. Furthermore, recognizing the importance of alternative disease management, particularly for this new disease, we are currently screening different Miscanthus populations for sources of disease resistance.

Acknowledgments This work was funded by the Energy Biosciences Institute. Miscanthus $\times$ giganteus 'Illinois' plugs used for this study were donated by Speedling Inc., Sun City, FL, USA. The authors are grateful to Douglas J. Maxwell and Lisa Gonzini of the Weed Research Unit, Crop Sciences Department, University of Illinois, for their help with the fungicide application.

Open Access This article is distributed under the terms of the Creative Commons Attribution License which permits any use, distribution, and reproduction in any medium, provided the original author(s) and the source are credited.

\section{References}

1. Agnetti F, Garaguso M, Moretta I, Danesi P, Moretti A, Rodolfi M (2011) Isolation of Pithomyces chartarum from Italian flocks affected by facial eczema. Mycoses 54:107-108

2. Ahonsi MO, Agindotan BO, Williams DW, Arundale R, Gray ME, Voigt TB, Bradley CA (2010) First report of Pithomyces chartarum causing a leaf blight of Miscanthus $\times$ giganteus in Kentucky. Plant Dis 94:480-481

3. Ahonsi MO, Agindotan BO, Gray ME, Bradley CA (2011) First report of basal stem rot and foliar blight caused by Pythium sylvaticum on Miscanthus sinensis in Illinois. Plant Dis 95:616-616

4. Anderson E, Arundale R, Maughan M, Oladeinde A, Wycislo A, Voigt T (2011) Growth and agronomy of Miscanthus $\times$ giganteus for biomass production. Biofuels 2:167-183

5. Beccari G, Covarelli L, Balmas V, Tosi L (2010) First report of Miscanthus $\times$ giganteus rhizome rot caused by Fusarium avenaceum, Fusarium oxysporum and Mucor hiemalis. Australian Plant Disease Notes 5:28-29

6. Christian DG, Lamptey JNL, Forde SMD, Plumb RT (1994) First report of barley yellow dwarf luteovirus on Miscanthus in the United-Kingdom. Eur J Plant Pathol 100:167-170

7. Collin RG, Towers NR (1995) Competition of a sporidesminproducing Pithomyces strain with a nontoxigenic Pithomyces strain. New Zeal Vet J 43:149-152

8. Di Menna ME, Smith BL, Miles CO (2009) A history of facial eczema (pithomycotoxicosis) research. New Zeal J Agr Res 52:345-376

9. Dinger E (ed) (1999) Facing up to facial eczema, revised edition. Wellington NZ, Norther Region Sheep Council, Lithoprint

10. Eken C, Jochum CC, Yuen GY (2006) First report of leaf spot of smooth bromegrass caused by Pithomyces chartarum in Nebraska. Plant Dis 90:108-108

11. Fitzgerald JM, Collin RG, Towers NR (1998) Biological control of sporidesmin-producing strains of Pithomyces chartarum by biocompetitive exclusion. Lett Appl Microbiol 26:17-21

12. Flaoyen A (2000) Plant-associated hepatogenous photosensitization diseases. Acs Sym Ser 745:204-219

13. Goßmann M (2000) Occurrence and pathogenicity of Fusarium spp. on Miscanthus $\times$ giganteus Greef \& Deu. (China grass). In: Nirenberg H (ed) 6th European Fusarium Seminar \& Third Cost 835 Workshop of Agriculturally Important Toxigenic Fungi, Berlin, 11-16 September 2000, p 91 
14. Grisham MP, Maroon-Lango CJ, Hale AL (2012) First report of sorghum mosaic virus causing mosaic in Miscanthus sinensis. Plant Dis 96:150

15. Hansen DE, Mccoy RD, Hedstrom OR, Snyder SP, Ballerstedt PB (1994) Photosensitization associated with exposure to Pithomyceschartarum in Lambs. J Am Vet Med Assoc 204:16681671

16. Heaton EA, Dohleman FG, Long SP (2008) Meeting US biofuel goals with less land: the potential of Miscanthus. Global Change Biol 14:2000-2014

17. Heaton EA, Dohleman FG, Miguez AF, Juvik JA, Lozovaya V, Widholm J, Zabotina OA, Mcisaac GF, David MB, Voigt TB, Boersma NN, Long SP (2010) Miscanthus: a promising biomass crop. Adv Bot Res 56:75-137

18. Hodkinson TR, Chase MW, Lledo MD, Salamin N, Renvoize SA (2002) Phylogenetics of Miscanthus, Saccharum and related genera (Saccharinae, Andropogoneae, Poaceae) based on DNA sequences from ITS nuclear ribosomal DNA and plastid trnL intron and trnL-F intergenic spacers. J Plant Res 115:381-392

19. Hum S (2005) Putative sporidesmin toxicity in an eastern grey kangaroo (Macropus giganteus). Aust Vet J 83:678-679

20. Hwang SF, Wang HP, Gossen BD, Chang KF, Turnbull GD, Howard RJ (2006) Impact of foliar diseases on photosynthesis, protein content and seed yield of alfalfa and efficacy of fungicide application. Eur J Plant Pathol 115:389-399

21. Lebars J, Oswald E, Lebars P, Bonnefoi M, Bezille P, Braun JP (1990) Ecotoxinogenesis of Pithomyces chartarum. Food Addit Contam 7:S19-S21

22. Little RC, Milliken GA, Stoup WW, Wolfinger RD, Schabenberger O (2006) SAS for mixed models SAS Institute Inc. Cary, NC, USA

23. Mekete T, Reynolds K, Lopez-Nicora HD, Gray ME, Niblack TL (2011) Plant-parasitic nematodes are potential pathogens of Miscanthus $\times$ giganteus and Panicum virgatum used for biofuels. Plant Dis 95:413-418

24. ONeill NR, Farr DF (1996) Miscanthus blight, a new foliar disease of ornamental grasses and sugarcane incited by Leptosphaeria sp, and its anamorphic state Stagonospora sp. Plant Dis 80:980-987
25. Parle JN, Menna MED (1972) Fungicides and control of Pithomyces chartarum.1. Laboratory trials. New Zeal J Agr Res $15: 48-53$

26. Parle JN, Menna MED (1972) Fungicides and control of Pithomyces chartarum.2. Field trials. New Zeal J Agr Res 15:54-63

27. Sharma ND, Joshi LK (1978) In vitro assay of some fungicides against Pithomyces chartarum (Berk and Curt) Ellis causing glume blotch disease of rice. Mysore J Agr Sci 12:113-115

28. Sinclair DP, Howe MW (1968) Effect of thiabendazole on Pithomyces chartarum (Berk+Curt) Mb Ellis. New Zeal J Agr Res 11:59

29. Smith BL, Towers NR (2002) Mycotoxicoses of grazing animals in New Zealand. New Zeal Vet J 50:28-34

30. Stutzenb F, Parle JN (1973) Effect of 2-substituted benzimidazoles on fungus Pithomyces chartarum. J Gen Microbiol 76:197-209

31. Thinggaard K (1997) Study of the role of Fusarium in the field establishment problem of Miscanthus. Acta Agr Scand B-S P 47:238-241

32. Toth B, Csosz M, Dijksterhuis J, Frisvad JC, Varga J (2007) Pithomyces chartarum as a pathogen of wheat. J Plant Pathol 89:405-408

33. van Wuijckhuise L, Snoep J, Cremers G, Duvivier A, Groeneveld A, Ottens W, van der Sar S (2006) First case of pithomycotoxicosis (facial eczema) in The Netherlands. Tijdschr Diergeneesk 131:858-861

34. Verma OP, Gupta RBL, Shivpuri A (2008) A new host for Pithomyces chartarum, the cause of a leaf spot disease on Withania somnifera. Plant Pathol 57:385-385

35. Wallace EGR (1976) A comparison of the control of Pithomyces chartarum with three fungicides applied at both the pre- and post-danger levels of spores in pastures. New Zeal J Exp Agr $4: 243-247$

36. Wilkinson HT (1988) Pithomyces chartarum isolated from Poa-pratensis Swards. Can J Bot 66:72-74

37. Wrenn NR, Wesselink C (1982) Comparison of a controlled droplet application and hydraulic nozzle spray systems for application of fungicide to control Pithomyces chartarum and reduce facial eczema in livestock. New Zeal J Exp Agr 10:451-454 